\title{
The 'Public' Nature of Higher Education in Italy: What Place for Autonomy and Variety?
}

GAETANO Luberto

\section{Introduction}

The attribution of 'publicness' to higher education outputs is derived from mainstream economics. According to this perspective, the public nature of higher education depends on the characteristics of the outputs provided by the universities: research, teaching, scholarship, learning, service, transmission of values and culture, the disinterested search for truth, professional competence, promotion of social and economic development, social mobility and equity, character building, and the development of critical reason are among the main (but not exhaustive) responsibilities that different stakeholders assign to the universities in various degrees and with emphasis depending on their preferences and interests.

The analytical problem of evaluating the nature of each of these outputs is still more complex since the assumption is that many if not most higher education 'goods' may be related to each other.

It is therefore understandable that we find great variety, diversity, and differentiation in higher education systems and institutions. We may ask whether such variety should be considered a 'good', even a 'public good', and whether it is connected with one of the fundamental peculiarity of the university: autonomy (Felt 2002).

After putting forth some theoretical considerations supporting the idea that there are strong correlations among variety, autonomy, and the public nature of higher education, I will examine the issue in the context 
of the Italian university system reform process. The aim is to show how the weak university autonomy and the absence of any institutional variety in Italian higher education is the result of an historical pattern that fostered centralisation and uniformity. Centralisation and uniformity have been the ideological cement that have made the 'public' nature of the higher education 'good' coincide with the values and interests of national politicians and ministerial bureaucrats, academic oligarchies, and professional bodies. As long as this pattern is still active in the reform process and even able to restore old practices, it decreases the publicness of higher education dependent on a high level of institutional autonomy and system variety.

\section{A firmer foundation for the public nature of science: variety}

According to Callon (1994), science is not public because of excludability and non-rivalry, but for the more fundamental reason that it is a source of variety. The variety of science is based on the continuous reconfiguration of local and heterogeneous networks which may or may not have reciprocal connections and links. It is the never-ending proliferation of such networks that makes science resistant to the rigidities and irreversibility of private science (and of the economic forces that support it). It is also true that public science (based on variety and exploration) and private science (based on replication and exploitation) are not opposite but complementary forces, each drawing on the other. Callon's analysis is supported by anecdotal evidence showing how the usual network size of peer reference groups, within which most scientists' work is carried out, amounts to 150-200 people. These are usually deeply specialised clusters of disciplines and sub-disciplines competing against each other on the basis of often incompatible analyses and prescriptions but that can also be nested in wider fields of studies that allow for exchanges of models, methodologies, and theories. Additionally, the possibility of creating new fields or networks is a check on the natural tendency of disciplines to ossify because of their unavoidable 'blind spots' (Lohmann, 2004). From the same socio-cognitive point of view, it can be shown that a relatively small network structure is more apt than other kinds of social structures to make effective scientists' most scarce resource: attention (Klamer and Van Dalen 2002).

It is legitimate to ask whether the proliferation of network and scientific variety runs against some kind of prescriptive limit. Callon does not think so and in the last part of his work suggests that interventions 
should always aim at assuring free association and participation to local networks, fostering an equal opportunity for all networks to expand, and fighting against irreversibility and convergence of predominant networks by "lending support to emergent collectives and encouraging their proliferation" (Callon 1994). Only in this way can one assure the "public' sufficient variety in knowledge production, otherwise threatened by the dynamics of real markets. Among the few supporting such a strong interventionist program is Fuller, who suggests that reversibility and fungibility should be priorities for funding science (Fuller 2000), pointing at Big Science as an example of social and epistemological rigidity.

The extension of interdisciplinary and intra-disciplinary variety and differentiation is hotly debated in the scientific enterprise. Traditional academic science tends to grow on relatively stable disciplines, while post academic science (Ziman 2000) and "mode 2" science (Nowotny et al. 2003) would see disciplines as modules for more relevant transdisciplinary and problem-oriented intellectual adventures. Internal variety and differentiation depend of course, on the type of discipline. 'Urban' and 'rural', 'soft' and 'hard' are social and intellectual dimensions that can impinge on the degree of proliferation of theories and methodologies (Becher and Trowler 2001). Analysing differences amongst scientific fields, Whitley (2000) identifies seven 'stable' types of social/reputation structures: conceptually and technologically integrated bureaucracies, polycentric professions, partitioned bureaucracies, polycentric oligarchies, and professional and fragmented adhocracies. In the introduction to the second edition of his book, Whitley states that the greater relevance of Mode 2 science as well as the growth of "explanatory instrumental sciences," as he suggests redefining disciplines included the Pasteur's quadrant (Stokes, 1997), based on both theoretical understanding and practical use, did not seem to cause "a convergence in prevalent patterns of intellectual and social organisation across the science, .....as variation in the structure of scientific fields remains significant" (Whitley 2000, pp. xxi-xxii).

Whitley's remark is congruent with the emerging compound of knowledge regimes coupled in various forms to actors' interests and alliances which bring about "different effects within different disciplines, with different fields of knowledge and within different states" (Bleiklie and Byrkjeflot 2002, p. 530).

Rip reinforces Callon's argument since, in his words

"emphasising heterogeneity, rather than reducing can be seen as a hedging strategy... (since) ...the links between science and society......counteract a too rapid lock-in into a protected regime of strategic science....(besides)...under 
conditions of uncertainty, it is only prudent to maintain variety... Heterogeneity is valuable in its own right." (2000, p. 34)

Heterogeneity is valuable because it counterbalances the natural tendency of normal and laboratory science to simplify the world to make it conform to strict methodological concerns or short-term control aims.

\section{Taking seriously the complexity of knowledge development process in higher education}

In higher education we find different types of scholarship (Boyer 1990; Braxton et al. 2002; Huber 2001): the scholarship of discovery, the scholarship of integration, the scholarship of teaching (and learning), and the scholarship of application (or engagement).

The scholarship of discovery is the activity leading to new and original propositions, models, theories, and visions about the natural and the social world. Its main product is the excellent research that puts the academic on the frontline of his or her discipline. Creation of original knowledge, priorities rules, and high-citations statistics are very important issues in this context. The scholarship of integration arises from the attempt to counterbalance the fact that the excellent research is usually pursued within strict disciplinary specialisations and paradigms. The former is therefore based on an interdisciplinary or thematic agenda aimed at fostering the awareness of both common grounds and real differences among diverging research theories or traditions. The elaboration of existing knowledge is the main purpose of the scholarship of integration: its products can range from the enlightening critical review of one or more related subjects to the basic textbook for undergraduate studies. The scholarship of application and engagement is developed through service and consulting activities, and reflection on the results of both. It is obvious that application and diffusion of knowledge is accomplished especially by those academics pursuing this kind of scholarship. The scholarship of teaching focuses on the study of the specific transmission of knowledge in academic settings having as its own objective the effectiveness of students' learning. The scholarship of teaching and learning must be distinguished by the activity of teaching: a distinct and formal role of faculty work consisting of the transmission of knowledge to well-defined subjects.

There is of course, overlap among and between the four different types of scholarships and the formal activity of teaching. For instance, 
students can learn from both transmission and application (internships, field and service work, etc.) at the same time. Effective teaching materials can be prepared in most cases, only if supported by complementary competences in the scholarship of integration and scholarship of teaching and learning. Action and clinical research cannot be understood without positing a vast overlap between the scholarship of application and that of discovery and/or integration. In Mode 2 science, the context of application is of utmost relevance for new discoveries. Each of these scholarships has some relevant connections with the teaching activity.

In light of this complexity, the positive and reciprocal externalities between teaching and research cannot be easily specified (Hughes 2004). Indeed, it is not surprising that statistical studies generally have found a null correlation between them (Marsh and Hattie 2002). As a deduction of the more fine grained approach I am proposing here, it should probably be recognised that the variety and diversification of academic competences and skills is one of the most neglected conditions for viability and growth of higher education.

A task environment characterised by high horizontal (disciplinary) and vertical complexity (across the different phases of knowledge creation, integration, transmission, application, and diffusion) requires specialised professional roles. For instance it is well known that, from an organisational point of view "research...requires specialisation and flexibility to follow new developments, (teaching) requires synthesis and more stable structures" (Enders 2001, p. 16).

How to manage interdependencies among the phases of the knowledge process development without falling back in the simplistic and unrealistic pretension that all the different aspects of scholarship, research, and teaching be included with the same weight and proportion in each and every academic role? As a matter of fact, a high number of important universities in Europe as well as the United States employ onlyteaching and only-research personnel. So, it might be more effective and practical to envisage that the integration of the different components of the knowledge process be the fundamental mission of university bodies and institutions. In this way, university status, interpreted as mainly derivative of homogeneous academic roles, can become a collective propriety of the academic institution. It is the institutions that should carry the main responsibility to find the most appropriate balance among different kinds of scholarship and different levels/segments of teaching. According to this perspective, the presence within the universities of academic roles differently combining teaching and scholarship tasks is fully intelligible and does not require ad hoc justifications, becoming, on 
the contrary, one of the fundamental sources of institutional variety and distinction.

The empirical scanning of higher education systems shows that behind the rhetorical stance this situation is almost the norm (Felt 2002; Nybom 2003; Schimank and Winnes 2000). In England, only research position amount to more $30 \%$ while only teaching positions are almost $10 \%$ of all positions (Hesa figures for 2000-01). In some U.S research universities (e.g., the University of California campuses) tenure track for only-teaching positions are included in the academic personnel structure (University of California 2002). To these positions can also be shifted, with their consensus, people from professorial roles. In most Scandinavian countries only teaching tenured lecture positions are quite common. In Germany, professors of Universities of Applied Sciences are required to spend most of their working time in teaching and professional activities. Even in more centralised higher education systems such as France and Italy the apparently rigid structure of academic roles covers a more differentiated situation. In France, research shows how differentiated in practice the academic role can be on the bases of the discipline, the institution, and the personal life project (Becquet and Musselin 2004); besides, it is useful to remind how in French universities many courses at the first level are taught by permanently detached secondary teachers; the need to face a complex reality has also brought the government to inquire about possible solutions usefully exploiting such variety (Espéret 2001). In Italy, along with permanent academic staff, universities are allowed to utilise temporary contract personnel with only teaching duties. In the academic year 2002-2003, the number of such personnel, responsible for at least one curricular teaching module but not including language instructors, was 22.195 against the 55.470 population of the permanent academic staff.

The activity of teaching distinguishes universities from research institutes and organisations. In this way they remain faithful to their historical Middle Age origins, though in order to draw a boundary with regard to other teaching institutions, university teaching must be fertilised with some kind of scholarship, not necessarily at the individual level but at a collective level (Fuller 2003; Lay 2004; Verger 1992).

The specificity of the universities and higher education institutions as social vehicles of the knowledge development process does not come from the fact that they are repositories only of the explorative phase in basic, pure, or curiosity driven research; but from the fact that their legitimate mission is also related to the exploitation and retention of knowledge (through transmission, diffusion, and application). Each and every university cannot avoid managing in its own singular way this 
trade-off by arranging appropriate intra-ecological evolution processes and dynamically situating itself within the co-evolutionary process that connects science, technology, and society (Rip 2002). The constantly active dynamics of apparently contradictory phenomena such as 'academic drift' or 'vocational drift' in higher education institutions reveals the difficulty to find a stable equilibrium point in managing the trade-off between different types of scholarships and teaching. On the other hand, the plurality of equilibria chosen by different institutions in pursuing their peculiar knowledge configurations might turn out to be the best adaptation to the changing social contract between the higher education system and society (Martin 2003).

\section{Some figures on the institutional and system performance of Italian higher education}

Statistical comparison with OECD countries and the 15 European Community countries before the enlargement are revealing at this point (OECD 2002). While the Italian GNP per capita is a little higher than that of OECD countries and the 15 European community countries before enlargement, higher education expenses are only $0,9 \%$ of GNP against the $1,3 \%$ of OECD countries and 1,2\% of the 15 European countries. Much of the gap comes from the lack of investment of the private sector but public funds for HE not only compensate but are even lower than both averages. Consequently, the yearly expense per tertiary student is also quite lower (7.550 equal purchasing power dollars against, 9.210 and 9.700 dollars respectively). Funds for scholarship are by far less than in most of these countries; likewise, the percentage of beds in university residence in 2001 was only $1.7 \%$ of the overall number of students (one third concentrated in three universities!), while in the comparable European nations (expect for Spain and Portugal), the same percentage ranges from $7 \%$ to $20 \%$.

Structural reasons and lack of funding have taken a toll on the performance of the higher education system. In 2001, the percentage of 2464 year old Italians holding a tertiary degree was 10\% (mostly four year degrees) against the $23 \%$ of OECD countries. The traditional neglect of the short-cycle degree explains only in part such a situation since the percentage of long-cycle undergraduate degrees in OECD is still higher ( $15 \%$ of the same population).

The fundamental problem however, is not a lack of participation in higher education (the enrolling rate of 19 years old in fact has jumped from $7 \%$ in 1960 to $62 \%$ in 2003 , thanks also to the new $3+2$ degree im- 
plemented since the year 2000-2001): the problem lies in the inability of the university system to adapt to the passage from an élite to a mass system. Guido Martinotti, the main consultant of the last government commission that planned the implementation of the Bologna declaration in Italy, has calculated that between 1960 and 2000 of the 9.187.154 youngsters that to access university studies in Italy, only 2.933 .307 $(31,93 \%)$ obtained a degree, often with a long delay over the planned four-five years nominal length (the success rate has increased only in recent years when it topped $42 \%$, but the average length of the course study is still around 7 years for most types of degrees). Lack of differentiation is one of the reasons for this low performance: for instance, more than half of the students are not full time, but the introduction of part-time has not brought about significant changes in teaching methods and arrangements (apart from the possibility to officially extend the length of study and be more or less unofficially, exempted from course attendance).

One of the main consequences of the incapacity to effectively manage the passage to mass higher education is on equity. Although fees and tuitions have been quite low in the past, and although most universities have followed open access policies, the percentage of students from lower economic conditions participating in higher education is stably low. Economic and sociology studies consistently highlight that formal equality in provision of higher education services does not foster social class mobility (Checchi et al. 1999; Schizzerotto 2002), but confirms traditional patterns that make higher education a welfare benefit for middle and high classes.

The lacking performance of Italian universities as a learning site for the would-be students also has a negative impact on its external attractiveness. International students are just $1 \%$ of the student population while the same average in the other European countries is above 6\%; similarly in Erasmus student mobility, Italy has shown a significant prevalence of outgoing over incoming students (in 2002-2003 the figures were 15.225 and 10.982 respectively). Foreign doctoral students in Italy are only $2 \%$ of the relative population, while the percentage in other comparable European countries goes from 6\% in Portugal to $35 \%$ in the United Kingdom.

The percentage of researchers by each 1000 workers in Italy is 2,8\% (one of the lowest in Europe where the average percentage is 5,4\%), while investment in research amounts to $1.07 \%$ of GNP vs. the $1.9 \%$ European average (European Commission, Key Figures, 2003). While most of the difference is due to poor private investments in $R \& D$, public investments do not compensate and are still lower than the OECD aver- 
age. The last comparative inquiry (King 2004) indicates that the 'quantitative' productivity of the system is satisfactory in areas such physics, mathematics, and engineering; while it lags in biological, health, and environment sciences where the traditional organisation of academic work has the most negative impact (Whitley 2003). However, it is at the institutional level that Italian universities show lagging research performance. In all the international comparative benchmark exercises (Center for Science and Technology Studies 2004; Shanghai Jiao Tong University-Institute of Higher Education 2004; The Times Higher Education Supplement 2004), Italian universities are situated in backward positions.

What seems to be lost is the potential for doing much better: as a matter of fact, intellectual brain drain is one of the highest in Europe. The percentage of graduates living outside Italy in 1999 (2.3\%) was seven times higher the percentages of foreign graduates living in Italy $(0,3)$, while in France, Germany, and England the latter figure is always higher than the former and in Spain the difference between the two is quite small (Becker et al. 2003).

In coherence with this scenario, the Italian research system also lags behind on the side of commercialising knowledge. In fact, the number of patents presented at the European Patent Office, per million population is less than half that of the before enlargement 15 European Community countries (67 vs. 154) (European Community Commission, Science, Technology, and Innovation, Key Figures 2002).

\section{Governance and management of Italian higher education: the weight of academic work organisation}

In the European context, the Italian higher education system is marked by some peculiar characteristics derived from its distant and recent past (Clark 1977; Giglioli 1979; Moscati 1997; Rugiu 1991). Clark's thesis, substantially confirmed by the later studies, is that until the 1970 s higher education in Italy may be seen as a system "strewn with barriers to competition: a monopoly controlled by an oligarchy through a bureaucracy"(Clark 1977). The absolute discretion of the chair holder in the monocratic institute remained opaque and devoid of any responsibility check for a long time. In this scenario, the formally legitimated centralisation of curricula, disciplines, administration, resource allocation, and recruitment procedures 
"means that neither market mechanism nor administered standards....are strongly operative ... (because of)..the oligarchic particularism..(that).. has triumphed over both bureaucratic universalism.... and market competitive forces." (Clark 1977)

The absence of any countervailing power in or outside the universities made it easy for chair holders to control higher university posts. This control was not targeted to strengthen the university as an institution since the interaction between single institutes, ministerial bureaucrats, and politicians was often managed individually by the chair holder. In this vein, Giglioli (1979) defines the Italian academic work organisation as a bureaucratic (for its utmost reliance on state rules and regulations) and patrimonial (for the quasi-private use of public resources by chair holders) system. Additionally, in the Italian case professional standards were also judged by Clark to be very weak; self-policing against patronage, favouritism, and opportunism as well as full support for academic quality work were hindered by the absence of universal professional association, independent journals, and other institutions of modern professions in dynamic capitalistic societies. Italian academic guilds were different from modern and contemporary professions where competition for income, assets, status, and reputations is very high since patronage depends on trust

"elicited collectively by requiring all practitioners systematically to submit to the critical appraisal of their peers. The result is an occupational subculture that tends to be acutely status conscious, but which also tolerates greater candor and higher levels of criticism and conflict than would be thought acceptable in most human communities." (Haskell 1997, p. 5)

Applying Whitley's (2000) typology, the social and organisational structure of the Italian academic system emerges as an oligarchic/bureaucratic hybrid. Substantial lack of open competition through debate, controversy, and open theoretical conflict lead us to categorise it as partitioned bureaucracy. The informality of coordination and control mechanisms within the insulated and separated national and local academic schools puts the system in the oligarchic sphere. The combined result is an arena of status integrated partitioned oligarchies, whose main objective is to preserve acquired status and asymmetrical relationships in and outside universities: in this arena the knowledge development process too often becomes a zero-sum game for positional goods, unless exogenous forces break the self supporting equilibria. 
Organisation of academic research by single institutes has been criticised for a long time (Ben-David 1991; Consolatio 1961; Herbst 2004), but only in Italy has

"the fusion of academic oligarchy and state bureaucracy... (been)...an ideal system for suppressing competition....for individual talent, institutional status based on talent, (and)...among operating units.” (Clark 1977, p. 125)

The diffusion of the departmental structure promoted by the 1980 reform law has not significantly changed the situation. Departments have substituted the old institutes in most universities, but this has meant no rupture at all. Departments have taken administrative roles while research is coordinated in sectional subgroups, and the most important decisions are still made in restricted Faculty Councils (Pitzalis 2002) although some universities have used the statutory autonomy to extend full decision and active elective rights to all tenured researchers.

Both Clark and Krause notice moreover, that the typical Italian chair holder was not only strictly intertwined with central bureaucracy, but also had strong relations with the professional, social, and political world. Many academics are parliamentary representatives; others play important roles in cultural and media institutions, in political parties, and in government. But the high presence of top academics in Italian society and institutions has never helped legitimise the requests of sufficient resources for higher education or contributed to consolidate the status of universities as collective instruments to pursue research and learning beyond their more routine and symbolic function of credential providers.

The present Italian higher education regime is the result of choices made after the unification of Italy accomplished by the Piedmontese reign in 1861 (Capano 1998, 1999; De Vivo and Genovesi 1986; Rugiu $1991)$ towards a very strong centralisation of decision-making power on academic, statutory, and administrative matters. Autonomy was further reduced by the choice to follow the French model in the recruitment of professors, reserving it to a central commission of the faculty corporation appointed by the ministry (who could also directly nominate some professor as in the German case). Institutional autonomy was therefore extremely low and limited to operational and ceremonial aspects.

Consequently, each university was given the same status (Capano 1998). It is on this base that il valore legale del titolo di studio (the legal value of the university degree) has begun to be used as an argument to justify this situation and neglect any other possible alternative. Centralised disciplines and subject formal uniformity was justified as the only way to assure that the same degree or title conferred by any university 
had the same value. Indeed, the delay in introducing doctoral degrees (established only in the 1980s), vocational sub-honour degrees and postgraduate specialisation degrees (allowed by the 1990s reforms), is well explained by the difficulty to reinterpret the concept of the 'legal value' of the study title for the new qualifications. Since the only legally defined 'doctor' was the holder of the four or five year bachelor degree, it was particularly difficult to legally rearrange content and uses of the new degrees. As a natural consequence, while the vocational 'university' diplomas introduced by law $n^{\circ} 341$ in 1990 substantially failed because they were not seen as valuable university degrees, the doctoral degree has taken the almost exclusive role to channel graduates towards a research career in academic and similar settings.

The centralisation of academic personnel recruitment was and still is justified by the need to maintain the legal value of university degrees, although the argument does not stand up on a comparative evaluation since such centralisation is also conspicuously absent in those continental European higher education systems where we find a structure of national university degrees.

The fascist regime stressed this side of centralisation even more, imposing on the professors an oath of allegiance that was refused by only 12 of 1225 chair holders. In the following years, relations between the fascist regime and the university became tighter and collaborative in many cases, while the surface of serious opposition had to wait for disasters brought about by World War II (Maiocchi, 2004). In the postwar period, centralisation of appointment remained, even though it was at times coupled by legislative initiatives turned to stabilise in the role, through non competitive qualification procedures, the categories of contractual teachers and researchers entered in the new emerging mass university system, but difficult to manage according to the rigid and slow recruitment system of the elitist university. By this time, however, centralised practices was responding more to the needs and interests of an academic corporation balkanised along, particularistic, ideological and political lines, than to an unitary vision of the state mission (Brierley 1999; Clark 1977; Clark 1983; Krause 1996; Rugiu 1991).

\section{A few steps towards autonomy and variety...}

A big change was implemented with the 1993 financial law which introduced a lump-sum model of funding to universities. In partial exchange for financial cuts, a substantial administrative and spending autonomy was granted to universities. Funding was concentrated on a lump-sum 
budget (the Fund for Ordinary Functioning of the university - FFO - including everything but central competitive research and infrastructure building money). As a consequence, a professor transferring to another university could no longer bring his salary and research money to the new place, so the patrimonial system, previously prospering inside the state bureaucracy, received an almost fatal blow. Additionally, since the funds going to each university were based for the largest quota on past expenses, while a small but growing quota (9\% in 2004) was linked to redistributive algorithms (to compensate under-funded universities) and incentive formulae (to improve teaching efficiency), room for pork-andbarrel manoeuvring was strongly reduced.

In 1998, a new law was approved which allowed a partial decentralisation of recruiting procedures, giving more voice to each university. The law was a compromise between those who aspired to give the university the right to choose their own academic staff and those who were faithful to centralisation. The evaluation commission is made up of four professors elected by the disciplinary national community and one chosen by the university; the university has the right to 'call' or not the one of the two candidates qualified by the commissions (in 2006 the possibility to qualify two candidates for each place was cancelled).

As a consequence of the new law, the number of full professor increased by almost $40 \%$ (from about 13.000 in 1999 to more than 18.000 in 2004) while the number of the other academic categories remained stable (about 18.000 associate professors and 21.000 researchers). Meanwhile, even though many researchers have been promoted to associate professors, the overall number of tenured academics has also increased from the about 50.000 in 1999 to little more than 57.000 in 2004.

The pressure of the Bologna Declaration has been the other fundamental exogenous variable on the change process. As if they had suddenly discovered the gaps in comparison with the more articulated systems of the other European countries, policy makers entered a frenzied period of reforms. In particular, the $3+2$ course structure (three-year laurea + two-year specialist laurea) along with the credit system was rapidly approved much sooner than in most other countries. In coherence with the tradition of centralised policies, the curricular structure was imposed on all universities, beginning in the academic year 2000-2001 (with the known exceptions in medicine, architecture, and engineering). Two thirds of the subjects were bounded to the national table, while discretion was allowed for the remaining one third. A recent Ministerial Decree (270/2004) increased the discretion for universities up to $50 \%$ of the overall first-level degree 180 credit and up to the $60 \%$ of the second- 
level 120 credit degree, though not for professional degrees such as Law for which university discretion has been strongly curtailed.

The process of implementation has produced strong resistance from traditional academicians and intellectuals (on both sides of the political spectrum), especially in some areas (humanities, law). The fear is of quality deterioration and fragmentation because of the new modular structure (Vaira 2003; Woolf 2003). But a much more powerful opposition has come from professional bodies which are afraid of the 'invasion' of the shorter degree graduates. The Minister, sensible to the potential vote of these large influential categories, issued a new decree 'reforming the reform' at the end of 2004. In place of the 3 year (180 credits) +2 year $(120$ credits) structure the Ministerial Decree from the 2005-2006 academic year activated, a ' $Y$ ' structure i.e., 1+2+2 model. According to this model, after a first common year (60 credits) in the various disciplinary areas, students will have to choose either the 'professional' pattern (other two years) leading to the first level degree or the 'theoretical/methodological' degree which allows the student to enter, after attaining the first degree, the second level (whose final title has been renamed laurea magistralis).

Under this provision, Italian universities will continue to enjoy a monopolistic position in tertiary education, since the option to create a tertiary non-university sector through complex public-private consortia co-financed by the European Community has a very limited scope (about 5000 students in almost 400 courses, according to the last ministerial inquiry).

The choice of the Minister partially contradicts the initial programmatic intention of the centre-right government to cancel the rapid implementation of the Bologna reform accomplished by the centre-left government ousted in 2001. An important, if not the most important reason for the detour, was that the reform has undeniably begun to give its first positive results. In the three years after the introduction of new shorter degrees (2001-2003), student enrolment has increased 19,6\%, while the percentage of nineteen years old youngsters over the total number of the same age youngsters went from $46.7 \%$ to $59,7 \%$; it has also increased the percentages from $16 \%$ to $21 \%$ for over 22 year old students (CNVSU - National Committee of Evaluation on the University System 2004). An even more remarkable improvement is the number of graduates which increased 57\% from 1999 to 2003 . Consequently, the percentage of fuori corso (students graduating after the regular number of study years) is finally decreasing. 


\section{7. ... and many steps backwards (through recentralisation of accountability practices and faculty recruitment)}

During the 1990s, Italian Universities received substantial forms of autonomy in statutory and financial matters as well as in teaching and recruiting policies. This autonomy was however, limited by policymakers' unwillingness to face and solve fundamental structural nodes such as the valore legale del titolo di studio, preserving total uniformity in a world of increasing pressures towards variety and autonomy.

While there are those who (even from their minority position) strongly criticise the totemic nature taken by the valore legale of university degree titles and its deleterious effect on the performance of the higher education system (Perotti 2002), many still defend it as preventive assurance against the loss of reputation that a single course or university could face in a more competitive environment.

The 2001 government change has allowed the political, bureaucratic, and academic forces opposed to autonomy and variety (but perfectly aligned to the Italian higher education tradition based on high uniformity and centralisation) to return and try to reverse the evolution of the past decade. Such an alliance (in part transversal to the political spectre) could not do much in opposing the Bologna reform since the performance of Italian higher education as a 'mass system' was too low and the external pressure of the Bologna reforms was clearly the only way to improve the situation of a static self-referential system devoid of any real incentive change.

But on other issues, the attempt to return to the past has begun and is still under way.

Apparently, the introduction in 2004 of formula-based performance budgeting is a step toward autonomy and output coordination allowing for autonomy on input and means choices (after 10 years of funding based on historical figures adjusted to correct the greater disparities among public outlays of similarly sized universities). More output responsibility for universities would mean more autonomy for the universities, but also more constraints for government to build a stable framework within which universities could develop their strategies more effectively.

An ambitious and costly RAE type initiative was also launched in 2004 to evaluate the excellence of research in all university research areas. This evaluation however, finished by the end of 2005 and repeated on a three-year cycle, has no planned relation with the performance budgeting initiative so one wonders whether it is intended to increase 
accountability of higher education institutions or discretionary choices of the political principal.

The creation of two different central advisory organisms, one for the evaluation of the overall university system - CNVSU and another to evaluate research (CIVR) is probably not only the legacy of a passion for redundant administrative structures, but it may be another sign of the will to have the possibility to choose the experts' opinion most convenient for political interests from time to time. This suspicion is strengthened by the dependent nature of the CIVR. Contrary to the English case, the CIVR is a dependent advisory structure of the Ministry directed by a Committee appointed at the discretion of the Minister. Furthermore the National Evaluation Committees on the University system (CNVSU) is under the strict political control of the Ministry and devoid of any authority over resource distribution. Such political dependence has been significantly revealed in the granting of legal university status to a small private Southern institution with no accreditation, no experience, no stable teacher bodies or operational funds; but entitled to a well connected centre-right local politician. Not even the strong denouncement of the Rectors Conference convinced the Minister and 'her' committee to recede.

The inclination of political masters (government and parliament) to centralise the decision-making power of the higher education governance structure and intervene in an opportunistic way has been confirmed in many other occasions.

Resources outside the formally predefined and transparent criteria of fund allocation have been attributed to faculties and universities with political and administrative clouts (indeed, by April of 2005 there was no official notice of the total funds assigned to each university for the 2004 fiscal year!).

At the beginning of 2005, universities were asked through a Ministerial Decree to elaborate within the following two months a three-year plan concerning the recruitment of teaching and non- teaching staff. Before authorising the recruitment process, the Ministerial bureaucracy will evaluate each plan on criteria that have not so far been communicated in the ordinance or in any other document. There was no indication about the likely financial resources available to the universities for the planning exercise.

New initiatives (from the new, and costly, Italian Institute of Technology of Genoa to the proposed change of academic personnel recruitment and juridical status) have been launched without any preliminary comparative research or serious consultation with the main stakeholders. 
Additionally, the Italian Minister was the only one (along with the Greek colleague) to initially oppose the establishment of a European Research Council which would subtract decision making powers from national bureaucracy and academic corporations.

It is particularly the law project to change the juridical status and recruitment process of the university teaching and research staff that clearly shows how the new alliance between parts of the political, bureaucratic, and academic worlds is trying to push back the forces of autonomy and variety that were beginning to prevail in the past decade. In fact, the primary purpose of the law project is to recentralise the most important choice a university can make to differentiate itself from other institutions: the definition of professional competences required to those who will be responsible for carrying out university institutional missions and the possibility to choose the personnel most suited to the specific combination of such missions that in practice, notwithstanding any unrealistic rhetoric, singles out each higher education institution.

The centralisation of recruitment procedure accomplished by closed number qualifications granted by national faculty commissions (whose appointment criteria are left to the discretion of the ministry) should guarantee the selection of candidates based on criteria of 'cosmopolitan' research excellence, but it is not clear at all how national commissions will be able to avoid the political negotiation and compromises of the past. Certainly, they will be responsible for the most important personnel choices, but they will not be responsible for the consequences of their choices on the universities. National commissions will be isolated from the contextual and specific needs of the universities; universities will lose the possibility to use academic personnel as leverage for their distinctive competence and missions. For instance, an Economics Faculty will be much less able to pick a Law teacher interested in the interdisciplinary discourse between law and economics, while for a Law Faculty it will be more difficult to avoid mathematically oriented economists disdaining the less formal institutional approaches. Centralisation occurs because universities are not trusted in their capacity to choose their own academic personnel inputs, but there are few signs that national commissions can be trusted to make the best choices for the system and for the involved university either.

It is interesting to note that centralised recruitment is almost absent in higher education systems of Western industrialised countries in full accordance with one of the distinctive aspect of medieval universities. The only exceptions are France and Spain. But even in French universities, competitions for tenured academic roles are local among candidates inserted yearly in open-ended national qualification lists (except for pro- 
fessors belonging to disciplines such as Law, Economics, and Management, particularly sensitive in a state-oriented culture). In Spain, the former centre-right introduced a centralist law which was strongly contested by universities and is now under revision by the new socialist government (CRUE - Spanish Conference of University Rectors 2004).

The 2002 Spanish law and the new Italian law project aim to obtain a homogenous professorial class through centralistic cooptation operated by national faculty guilds. In both cases universities are allowed to increase (up to $50 \%$ of the total) the percentage of fixed-term contractual teachers and researchers easily replaceable since they have no formal 'internal labour market' rights, not even a 'tenure track' perspective. This evolution appears in sharp contrast to the introduction of the 'Junior Professor' in German universities, mainly motivated by the need to assure full autonomy of teaching and research to young beginning academicians (Federal Ministry of Education and Research 2005).

If the Italian law project is approved a very large casualised teaching and research work force probably will be used for vocational courses and as a reservoir for academic careers under the strict control of full professors. Teaching will therefore continue to be considered a subsidiary, demeaning endeavour unable to find the stability and status needed to accumulate relevant knowledge and develop effective practices.

In absence of any formal or informal mobility rules for Ph.D. students and researchers, the risk is high that young non-tenured researchers will be maintained in a status of substantial 'fief' dependency, fostering a level of conformity not particularly congruent with contemporary hypercompetitive international research. The likely result will be 'the worst of all possible worlds' for autonomy and variety in academic work at the beginning of a career: top-down pressures to homogeneity from national guilds and analogous bottom pressures from local oligarchies.

In addition, there are evident signs of a return to a bureaucratic and patrimonial vision of the university personnel structure. The same law project removes any impediments for professors to engage in professional and commercial activities external to universities (the only duty being to annually spend 350 hours for university work at the university of which 120 should be delivered as official classes compared to the present 60 hours). The bureaucratic-patrimonial trend is further confirmed by the new code of patent rights that the Government is trying to approve in a separate bill. If this bill is approved, Italy will be one of the very few industrialised countries to exclude universities from the patenting rights of inventions and innovations carried out by its academic personnel (Dragotti 2004)! 


\section{Conclusions}

Reforms enacted in Italian higher education during the past 15 years gave some autonomy to universities in governance, financial, curricular, and personnel matters in order to improve a very low institutional and system performance. However, the unsolved tension and contradictions inside the reform process as well as the reactions of those opposed for different reasons (Luzzatto and Moscati 2005), have caused new political interventions in the direction of even lesser formally differentiated scenarios and towards recentralisation.

State and disciplinary centralisation, reinforced through alliances with professional bodies and faculty recruitment at the national level, thwart teaching and research innovations; evaluation systems are going to be based on performance-based indicators but at the same time, a reliance on discretionary bureaucratic means of control is increasing. Also, governance reforms for universities are being studied which reduce the previously awarded governance and statutory discretionary power (we did not deal with this issue here, since public debate has just begun). A particular aspect of the Italian situation is the rhetorical use of the valore legale del titolo di studio (legal value of the degree) to justify full-range standardisation of university inputs and outputs.

Under this perspective, no contradiction should be expected between some features of 'academic capitalism' (casualisation of lower teaching and research roles, polarisation of academic workforce, elimination of boundaries between professional interests and university missions) and the traditional Italian bureaucratic/oligarchic academic governance (state interference, bureaucratic controls, weakened institutional autonomy). On the contrary, the appeal to the public nature of higher education is useful to conceal the patrimonial private-like running of higher education institutions both at micro and macro level.

If universities are downgraded to mere means of political, bureaucratic, and academic groups coalesced at the national levels with hierarchical connections to the local level, many of the essential conditions allowing universities to function as vital knowledge vehicles (autonomy and variety) tend to be lost. In addition, the identification of the 'public' dimension with the national state overlooks the fact that international arrangements, non-profit institutions, and community governance may produce more and better public or 'associative' goods than a centralised national system (Marginson 2004). This is particularly evident in the case of the Italian higher education system where alliances among political, academic, bureaucratic, and professional groups are trying to counteract the forces of variety, diversity, and autonomy that would up- 
set lots of status positions and socio-economic rents enjoyed in virtue of a monopolistic power reinforced by its 'public' nature. In a more significant way, the 'conservative' groups are well aware that more autonomy and variety would endanger their standardised view of academic work as well their uniform and limited ideology of what a university should be.

\section{References}

Becher, T. and Trowler, P.R. (2001). Academic Tribes and Territories. Buckingham: Open University Press.

Becker, S.O., Ichino, A. and Peri, G. (2003). 'How Large is the 'Brain Drain' from Italy?'. CESifo Working Paper No. 839, Munich.

Becquet, V. and Musselin, C. (2004). Variations autour du travail des universitaires. Paris: Convention MENRT, ACI 'Travail'.

Ben-David, J. (1991). Scientific Growth. Essays in the Social Organization and Ethos of Science. Berkeley: University of California Press.

Bleiklie, I. and Byrkjeflot, H. (2002). 'Changing knowledge regimes: Universities in a new research environment', Higher Education, October-December, 44, 2-3, 519-540.

Boyer, E.L. (1990). Scholarship Reconsidered. Priorities of the Professoriate. San Francisco: Jossey-Bass.

Braxton, J.M., Luckey, W. and Helland, H. (2002). Institutionalizing a Broader View of Scholarship into Colleges and Universities through Boyer's Four Domains. San Francisco: Jossey-Bass.

Brierley, W. (1999). 'Italy: A Corporation Controlling a System in Collapse', in Farnham, D. (ed.), Managing academic staff in changing university systems. International trends and comparisons. Buchingham: Open University Press, pp. 131-157.

Callon, M. (1994). 'Is Science a Public Good?', Science, Technology \& Human Values, 19, 4, 394-424.

Capano, G. (1998). La politica universitaria. Bologna: Il Mulino.

Capano, G. (1999). 'Italy: the endless transition', in Braun, D. and Merrien, F. (eds.), Towards a new model of governance for universities? A comparative View. London: Jessica Kingsley, pp. 195-219.

Center for Science and Technology Studies (2004). Universities and Colleges Participating in the Champions League: Rankings by four Performance Indicators, 1998-2002. Bern.

Checchi, D., Ichino, A. and Rustichini, A. (1999). 'More equal but less mobile? Education financing and intergenerational mobility in Italy ans US', Journal of Public Economics, 74, 3, 351-393. 
Clark, B.R. (1977). Academic Power in Italy. Bureaucracy and oligarchy in a National University System. Chicago: University of Chicago Press.

Clark , B.R. (1983). The Higher Education System. Academic Organization in Cross-National Perspective. Berkeley: University of California Press.

Consolatio, W.V. (1961). 'Dilemma of Academic Biology in Europe. University Customs Steeped in the Past Make Difficult the Development and Retention of Creative Scientist', Science, 133, 3468, 1892-1896.

Dragotti, G. (2004). 'L'ateneo resta senza brevetti', Il Sole 24Ore, November 17.

Enders, J. (2001). 'Between State Control and Academic Capitalism: A Comparative Perspective on Academic Staff in Europe', in Enders, J. (ed.), Academic Staff in Europe. Changing Context and Conditions. Greenwood Press: London, pp. 1-23.

Espéret, É. (2001). 'Nouvelle définition des tâches des enseignants et des enseignants chercheurs dans 1'enseignement supérieur français', Éric Espéret. http://www.ladocumentationfrancaise.fr/rapports-publics/014000710/.

Federal Ministry of Education and Research (2005). 'Junior Professorship', Science. http://www.bmbf.de/en/820.php.

Felt, U. (2002). University Autonomy in Europe: Changing Paradigms in Higher Education Policy. Bologna: The Magna Charta Observatory of Fundamental University Values and Rights, Università di Bologna.

Fuller, S. (2000). The Governance of Science. Buckingham: Open University Press.

Fuller, S. (2003). 'The university: a social technology for producing universal knowledge', Technology in Society, 25, 2, 217-234.

Giglioli, P.P. (1979). Baroni e burocrati: il ceto accademico italiano. Bologna: Il Mulino.

Haskell, T.L. (1997). 'The New Aristocracy'. The New York Review of Books. December 4.

Herbst, M. (2004). 'The Production-Morphology Nexus of Research University: The Atlantic Split', Higher Education Policy, 17, 1, 521.

Huber, M.T. (2001). 'Balancing acts: Designing careers around the scholarship of teaching', Change, 4, 21-30.

Hughes, M. (2004). 'The Relationships Between Research and Teaching in Higher Education. A Review of the Literature 1990-2002'. Occasional Paper- N.2, Brighton Business School, University of Brighton. 
King, D.A. (2004). 'The scientific impact of nations. What different countries get for their research spending', Nature, 430, 311-316.

Klamer, A. and van Dalen, H.P. (2002). 'Attention and the art of scientific publishing', Journal of Economic Methodology, 9, 3, 289-315.

Krause, E.A. (1996). Death of the Guilds: Professions, States, and the Advance of Capitalism, 1930 to the Present. New Haven: Yale University Press.

Lay, S. (2004). The Interpretation of the Magna Charta Universitatum and Its Principles. Bologna: Bologna University Press.

Lohmann, S. (2004). 'A Toy Model of Scientific Progress', American Journal of Economics and Sociology, 68, 167-181.

Luzzatto G. and Moscati R. (2005). 'University Reform in Italy: Fears, Expextations and Contradictions', in Gornitzka, A., Kogan, M. and Amaral A. (eds.), Reform and Change in Higher Education. Analysing Policy Implementation. Dordrecht: Springer, pp. 153-168.

Maiocchi, R. (2004). Scienza e fascismo. Roma: Carocci.

Marginson, S. (2004). 'Doing somersaults in Enschede: Rethinking and inverting the public-private distinction in higher education, in the light of globalisation'. Presented at the Public-Private Dynamics in Higher Education: Expectations, Developments and Outcomes, Enschede.

Marsh, H.W. and Hattie, J. (2002). 'The Relation Between Research Productivity and Teaching Effectiveness: Complementary, Antagonistic, or Independent Constructs', Journal of Higher Education, September/October, 73, 5, 603-641.

Martin, B.R. (2003). 'The changing social contract for science and the evolution of the university', in Geuna, A., Salter, A.J. and Steinmueller, W.E. (eds.), Science and Innovation. Rethinking the Rationales for Funding and Governance. Cheltenham (UK): Edward Elgar.

Moscati, R. (1997). Chi governa l'università?: Il mondo accademico italiano tra conservazione e mutamento. Napoli: Liguori.

National Committee of Evaluation on the University System - CNVSU (2004). Rapporto annuali sullo stato delle università: http://www. cnvsu.it/publidoc/datistat/default.asp?id_documento_padre $=11237$.

Nowotny, H., Scott, P. and Gibbons, M. (2003). 'Introduction: 'Mode 2' Revisited: The New Production of Knowledge', Minerva, 3, 179194.

Nybom, T. (2003). 'The Humboldt Legacy: Reflections on the Past, Present, and Future of the European University', Higher Education Policy, 2, 141-159. 
OECD (2002). Education at a Glance: OECD Indicators 2002 Edition. Paris: OECD.

Perotti, R. (2002). 'The Italian University System: Rules vs. Incentives'. Presented at the ISAE conference on 'Monitoring Italy', Rome.

Pitzalis, M. (2002). Réforms et continuités dans l'Université italienne. Paris: L'Harmattan.

Rip, A. (2000). 'Fashions, Lock-ins and the Heterogeneity of Knowledge Production', in Merle, J. and Hellstrom, T. (eds.), The Future of Knowledge Production in the Academy. Buckingham: The Society for Research, into Higher Education and Open University Press, pp. 28-39.

Rip, A. (2002). 'Science for the $21^{\text {st }}$ Century', in Tindemans, P., VerrijnStuart, A. and Visser, R. (eds.), The Future of the Sciences and Humanities. Amsterdam: University Press, pp. 99-148.

Rugiu, A.S. (1991). Chiarissimi e magnifici. Il professore nell'università italiana (dal 1700 al 2000). Firenze: La Nuova Italia.

Schimank, U. and Winnes, M. (2000). 'Beyond Humboldt? The relationship between teaching and research in european university systems', Science and Public Policy, 27, 6, 397-408.

Schizzerotto, A. (2002). Vite ineguali. Bologna: Il Mulino.

Shanghai Jiao Tong University-Institute of Higher Education (2004). Academic Ranking of World Universities. http://ed.sjtu.edu.cn/rank/ 2004/2004Main.htm

Spanish Conference of University Rectors - CRUE (2004). Documento de la Asamblea General de la CRUE sobre cambios en la LOU y orientaciones de las politicas universitarias. http://www.crue.org/ pdf/asambleacrue20041.pdf

Stokes, D.E. (1997). Pasteur's Quadrant: Basic Science and Technological Innovation. Washington: Brooking Institution Press.

The Times Higher Education Supplement (2004). World University Rankings. November 5.

University of California (2002). University of California Academic Personnel Manual. http://www.ucop.edu/acadadv/acadpers/apm

Vaira, M. (2003). 'Higher Education Reform in Italy: an Institutional Analysis and a First Appraisal', Higher Education Policy, 2, 179197.

Verger, J. (1992). 'Patterns', in de Ridder-Symoens, H. (ed.), A History of the University in Europe. Volume 1. Universities in the Middle Ages. Cambridge: Cambridge University Press, pp. 35-74.

de Vivo, F. and Genovesi, G. (1986). Cento anni di università: l'istruzione superiore in Italia dall' Unità ai nostri giorni. Napoli: Edizioni Scientifiche Italiane. 
Whitley, R. (2000). The Intellectual and Social Organization of the Sciences $\left(2^{\text {nd }}\right.$ ed.). New York: Oxford University Press.

Whitley, R. (2003). 'Competition and pluralism in the public sciences: the impact of institutional frameworks on the organisation of academic science', Research Policy, 32, 6, 1015-1029.

Woolf, S. (2003). 'On University Reform in Italy: Contradictions and Power Relations in Structure and Function', Minerva, 41, 347-363.

Ziman, J. (2000). Real Science. What it is, and what it means. Cambridge: Cambridge University Press. 